\title{
Music and medicine
}

This article was published in the following Dove Press journal:

Journal of Multidisciplinary Healthcare

13 August 2010

Number of times this article has been viewed

\author{
Donatella Lippi' \\ Paolo Roberti di Sarsina ${ }^{2}$ \\ John Patrick D’Elios' \\ 'History of Medicine, Department \\ of Anatomy, Histology, and Forensic \\ Medicine, University of Florence, \\ Florence, Italy; ${ }^{2}$ Health Local Unit, \\ Department of Mental Health, \\ Bologna, Italy
}

\begin{abstract}
Healing sounds have always been considered in the past an important aid in medical practice, and nowadays, medicine has confirmed the efficacy of music therapy in many diseases. The aim of this study is to assess the curative power of music, in the frame of the current clinical relationship.
\end{abstract}

Keywords: history of medicine, medical humanities, healing music

\section{Introduction}

\section{Is medicine an art or a science?}

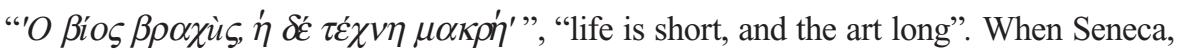
in the 1 st century AD, translated this Hippocratic aphorism using the Latin term ars to interpret the Greek word " $\tau \dot{\varepsilon} \chi v \eta$ " "art", an eternal question about the nature of medicine was asked: is medicine an art or a science?

The relationship between Medicine and Artes is very old, but it is not out of fashion at all: the necessity of artistic elements in the decoration of sanitary structures and the efficacy of narrative-based medicine (NBM) are currently being evaluated, and these questions can be considered the most important signs of a very profound change, one that is still in progress.

\section{The scientific triumphalism of the 20th century}

This critical approach to current medicine can be regarded as a consequence of the crisis, caused by the scientific triumphalism of the 20th century: the hyper-specialism and the increased use of technology progressively diminished the doctor-patient relationship. Moreover, this model of medicine did not succeed in properly facing the epidemiological transaction which was taking place in that period, when acute and infective diseases were replaced by chronic and degenerative pathologies. In this situation, a patient feels unsatisfied with the health system and increasingly turns to other kinds of medicine, as well as looks for a more human and caring therapist.

Clinical medicine in fact is based on scientific knowledge, technology, problem-solving, and decisions, but it is also a relationship between human beings, who have a body and soul, and biological equipment together with emotions, feelings, expectations, and fears.

\section{The re-humanization of medicine}

From this point of view, the re-humanization of medicine has become a primary requirement nowadays: as a result of this new awareness, in the 1980s, the World 
Health Organization provided a different concept of health care, which underlined the social and subjective component of wellbeing. The biomedical pattern of medicine had to be transformed into a biopsychosocial model, in order to draw the physician's attention to the organic aspects of the disease and to its social, behavioral, and psychological features. In this way, it would be possible not only to explain a phenomenon, but also to understand it, trying not merely to cure a patient through a medical treatment, but to take care of the person, with particular attention to the interpersonal relationship, the governance of sanitary institutions, the problems of research, and the education of health care practitioners.

With the aim of medicine being to take care of the sick (disease/illness) rather than to cure the disease, medical humanities have become increasingly widespread. ${ }^{1}$ However, it must not be considered a divertissement of the physician, who tries to embellish his daily work painting or playing music, in order to reduce the rigorousness of evidence-based medicine (EBM). At the same time, going beyond the list of notions, which could be comprised in the "Human Sciences", their most significant feature is a methodological approach, based on a historical-narrative paradigm, instead that of the logic-formal ground, that is typical of the hard sciences. ${ }^{2}$

\section{The importance of medical Humanities}

Medical Humanities are transversal privileged instruments for understanding and curing, as they provide training in the use of critical sense, a problematic method, and a comparative approach; at the same time, values of empathy are taught. Other skills also find a place in this historical-narrative epistemology, which deal with such different matters as works of art, literature, movies, and music. ${ }^{3}$ These innovative communicative forms can play a very important role in the diagnostic ${ }^{4}$ process and in the therapeutic practice as well.

\section{EBM and NBM should collaborate}

These observations however must not be considered contrary or supplementary to current medicine: EBM is not on one side, with $\mathrm{NBM}^{5}$ on the other one. It is not a fight between acronyms. As a matter of fact, EBM reduces the uncertainty of knowledge, and NBM improves the relationship between people. A novel, painting, or musical composition can be indicative of a culture and a historical period, but they can also give voice to different experiences, documenting particular situations and points of view. According to Latin writers, ${ }^{6}$ they also have the power to console.
In this context, music reclaims its original role as a companion to both the healthy and the sick. Following this renewed concept of health, in recent years, the relationship between music and medicine has been studied extensively, especially as regards the use of music in therapeutic practice, as well as an explanation of the neurological mechanism involved and bringing up new educational, scientific, and professional items.

Talking about music therapy has become very common, underlining its very old tradition, which goes back to the classical world and the Western Middle Age: these practices were then enriched by the influences of other cultures, often from very far away, and they became the topic of many treatises, above all in the 18th and 19th centuries.

\section{History}

\section{The classical world}

It is not by chance that in the classical world, the god Phoebus/ Apollon was considered the protector of medicine and music: he was the father of Asclepios/Aesculapius, who had learned medicine from the centaur Chiron. In the ancient world, there existed many musical expressions that were tied to different situations and were considered characteristic of different circumstances, in a symbiosis of poetry, song, and music, with voices as well as instruments.

Every scale, according to the Greek musical theory handed down to the Middle Age particularly by Boethius ligia, frigia, and dorica - and their different modi and genera, could induce different behaviors and conducts. Following the theory of the musical " $\dot{\varepsilon} \theta o \zeta$ ", "custom" music could influence the state of the soul, but also its volitional faculty: the energetic ' $\varepsilon \theta o \varsigma$ produced an act of the will, the enervating ' $\dot{\varepsilon} \theta 0 \varsigma$ paralyzed it while the ecstatic ${ }^{\varepsilon} \theta 0 \varsigma$ produced a state of inebriation. It was Aristossenus, who definitively stated the rules of rhythm and harmony, and named these different kinds of music as disthatic, sisthaltic, hesicastic.

\section{The middle ages and the renaissance}

During the Middle Ages, this theory was transposed to the eight Gregorian modi, even without the strict and univocal correspondence between modi and their effects, which had marked the classical theory of the modal ethos.

The belief that the use of different musical scales had different psychological effects remained alive in the Western musical tradition during the Renaissance, surviving also in the romantic consideration of the tonal ethos.

This attention to the effects of music, however, was deeply influenced also by the humoral theory of medicine, which 
considered health a balance of the body's fluids. From this point of view, one of the most significant pathologies which permits evaluating the importance of the therapeutic use of music is melancholy, which was considered to be caused by a surplus of black bile, thus inducing the well known habitus painted by Dürer. Medical treatises from Middle Ages ${ }^{7}$ to the Renaissance recommended treating melancholy by listening to music, warning from the use of inappropriate melodies, which could have provoked the opposite effects. ${ }^{8}$

Music was considered able to restore the balance between the soul and its faculties, thanks to its greatly emotive power, but which at the same time is governed by the same mathematical rules which were stated in the classical world and which had been codified in the theory of the soul and its faculties as worked out by Aristotle and Galen. ${ }^{9}$

\section{The 18th century}

These observations increased during the 18th century, giving rise to a rich series of studies, directed at discovering the effects of music on people affected by different pathologies: in many cases, although music was used to improve therapy, it was also considered to share the same approach of animal magnetism and mesmerism, which were spreading at that time. ${ }^{10}$

Franz Anton Mesmer, physician and musician, was a strong supporter of the vitalistic theories. He believed that organic processes had to be attributed to a hypothetical vital fluid, which was thought to permeate the whole universe. The physics of electricity and magnetism were starting to be disseminated, and Mesmer invented a physiological system where the harmonic flow of animal magnetism through the body resulted in its functioning. Diseases and dysfunctions were caused by blockages, imbalances, or difficulties of the downward flow of the fluid itself. Treatment was based on the application of magnets to the related parts of the body, but later was supplemented by ingenious and theatrical variants and by the induction of altered states of consciousness. Despite the lack of scientific grounds, this theory had great success, above all in the aristocratic and high-bourgeois classes of Paris as well as widely spread and followed, as its quotation in Mozart's opera Cosi fan tutte. ${ }^{11}$

Also Novalis and Schelling sustained that nature was ruled by a vital principle, comprehensible only through intuition, aesthetics and mysticism, while Georg Ernst Stahl (1660-1734) suggested the existence in every living being of a "sensitive soul", that ruled the physiological processes, a motor tonicus, whose modulations caused the events of life and also caused diseases, interpreted as an intensification or a reduction of the vital fluid itself.
For Stahl, almost every pathological sign was caused by a determined intention of the soul: the very general subject of the disease is a detail though, which can be considered an expression of the soul's unconscious choice, a perturbata idea of the management of the animal economy. The soul communicates odd impulses to the body, which create functional disorders. For this reason, the physician has a very limited capacity to act on the pathological conditions, but he can be minister naturae: if medicine cannot influence the body's structure, the physician can rouse, prevent, and attenuate some limited vital movements.

\section{Vitalism}

Vitalism was borne in Germany during the 18th century and was launched again by John Brown in Great Britain, quickly spreading to France and through the whole of Europe until the mid-19th century: Brown divided all pathologies into hypersthenic and hyposthenic ones, depending on whatever they were caused by, an excess or a decrease of the vital fluid. The principle of excitability was the ground of every organic response and it could change into a pathological condition: if excitability increased to create an excess of the vital fluid, it would be necessary to reduce it with proper treatment, such as blood lettings, leeches, enemas, emetics, or clysters. Broussais in France and Rasori in Italy spread this approach, supplementing it with personal contributions. The common element to all these theories, although very different from each other, was the strong belief that a vital fluid existed that could manage vital manifestations.

In this context, music would surely have had determinant effects, exercising its power and its efficacy on this fluid. The diffusion of medical treatises about this subject is not surprising, as music was considered a strategy for improving the correct flow of the vital fluid and the soul's wellbeing, which played a very important role in the occurrence of disease and in recovering one's health. ${ }^{12-15}$

From this point of view, every element which could influence the soul, was considered a real therapy: ${ }^{10}$

“... qu n'a-t-on pas dit sur la proprieté médicatrice du son? $[\ldots]$

L'ame ... disposée par la nature au plaisir de la musique, ne sait trop comment lui arrivent ces sensations, tantôt agréable, tantôt pénibles, qui résultent des sons...

$[\ldots]$

... La musique a une très-grande influence sur l'ame, parce qu'elle peut faire naitre dans l'esprit des idées absolutement différentes de celles qu' expriment les sons dont elle est composée..." 


\section{Looking for evidence}

When Vitalism set, defeated by a new, positivistic science looking for evidences, the role of music changed, very often becoming only of spiritual gratification.

However, in recent times, a revaluation of the musical component in medical treatments has begun to be performed programmatically in the USA. During the two world wars, music was used in hospitals to improve traumas and wound treatments, through both an active approach (playing) and a passive one (listening).

Other studies analyzed the relationship between the physics of sound and the psyhconeuroimmunoendocrinologic system, trying to investigate the methodology of its use, the evaluation systems, and scientific and applicative research in the field of prevention, rehabilitation, and therapeutics. ${ }^{16-21}$

The control of chronic cancer pain by music has been extensively investigated. ${ }^{22}$ Music therapy is extremely beneficial in cancer patients; music indeed has been proven in oncologic patients to reduce pain, to promote wellness in their daily lives, and to increase sense of control. ${ }^{23}$ Furthermore, music decreases anxiety, reduces psychological and physical symptoms, and helps to increase host immunity. ${ }^{24-31}$

It is of note that in patients with acute myocardial infarction, relaxation and music therapy have been effective in reducing stress. ${ }^{32}$ In an investigation, 80 patients were randomly assigned to a relaxation, music therapy, or control group. The relaxation and music therapy groups participated in three sessions over a 2-day period. Stress was evaluated via apical heart rates, peripheral temperatures, cardiac complications, and qualitative patient evaluative data. Results demonstrated that apical heart rates were lower and peripheral temperatures were higher in the relaxation and music therapy groups than in the control group. ${ }^{33}$

The relationship between coronary heart disease and reductions in anxiety states has been investigated. ${ }^{34-36}$ In one study, music was introduced into the private hospital rooms of 45 patients with myocardial infarction. A Holter monitor was attached to each participant, and they were asked to complete the State Trait Anxiety Inventory. Baseline physiological values were established. After listening to relaxing music for 20 minutes, participants exhibited significant reductions in myocardial oxygen demand, heart rate, respiratory rate, and anxiety, both immediately after and then one hour later. ${ }^{25}$

\section{Conclusion}

The involvement of music in the world of medicine, which can now rely on scientific evidence, ${ }^{37}$ is a return to a new concept of health, where the harmonies, which play in Dante's Purgatorio, accompany him on his journey towards a salushealth which, at the same time, is a high idea of salvation.

\section{Acknowledgment}

We wish to thank the Medical School of the University of Florence for supporting our studies.

\section{Disclosure}

The authors reports no conflicts of interest in this work.

\section{References}

1. Zannini L. Medical Humanities e medicina narrativa. Nuove prospettive nella formazione dei professionisti della cura. Milano, Italia; Cortina Raffaello: 2008.

2. Evans M. Reflections on the humanities in medical education. Med Educ. 2002;36(6):508-513.

3. Steffen H. On the theory and practice of musicotherapy between 1770 and 1830. Med Monatsschr. 1969;23(1):21-30.

4. Persson E. "Sick music" - experienced illness that set traces in music. Lakartidnigen. 2007;104(10):803-804.

5. Charon R. Narrative medicine: form, function, and ethics. Ann Intern Med. 2001;134:83-87.

6. Masini V. Medicina narrativa. Comunicazione empatica ed interazione dinamica nella relazione medico-paziente. Milano, Italia: Franco Angeli; 2005.

7. Duft J. Notker der Arzt: Klostermedizin und Mönchsarrzt im frühmittelalterlichen. St. Gallen: St. Gall; 1972.

8. Col de Villars E. An melancholicis musica. Paris; 1737.

9. Dupre'- E, Nathan M. Le langage musical: étude médico-psychologique. Paris: Alcan; 1911.

10. Roger JL. Traité des effets de la musique sur le corps humain. Paris; Brunot; 1803

11. Kluge CA. Versuch einer Darstellung des animalischen Magnetismus als Heilmittel. Vienna: F. Staar; 1815.

12. Lippius J. Disputatio de musica. Wittenberg: J. Gorman; 1609.

13. Regnier N. An musica in morbis. Paris; 1624.

14. Sprengel K. De musicae artis cum medicina connubio. Halle; 1800.

15. Leichtenthal P. Der musikalische Arzt, oder Abhandlung von dem Einfluss der Musik auf dem Körper und von ihren Anwendung in gewissen Krankheiten. Wien: Wappler und Beck; 1807.

16. Brewer JF. Healing sounds. Complement Ther Nurs Midwifery. 1998;4(1):7-12.

17. Bunt L. Music Therapy, An Art Beyond Words. New York, NY: Rontledge; 1994.

18. Chan YM, Lee PW, Ng TY, Ngan HY, Wong LC. The use of music to reduce anxiety for patiens undergoing colposcopy; a randomized trial. Gynecol Oncol. 2003;91(1):213-217.

19. Gfeller K. Therapeutic power of music. Currents. 2003;4(3).

20. Tse MM, Chan MF, Benzie IF. The effect of music therapy on postoperative pain, heart rate, systolic blood pressure and analgesic use following nasal surgery. J Pain Palliat Care Pharmacoter. 2005;19(3):21-29.

21. Six N. La musique au cabinet dentaire: de l'ambience musicale à la relaxation musicale. Lille: Tesi di Laurea; 2008.

22. Aldridge D. Music therapy research 1: a review of the medical research literature within a general context of music therapy research. Arts Psychother. 1993;20(1):11-35.

23. Beck S. The therapeutic use of music for cancer-related pain. Oncol Nurs Forum. 1991;18(8):1327-1337.

24. Hirsch S, Meckes D. Treatment of the whole person: incorporating emergent perspectives in collaborative medicine, empowerment, and music therapy. J Psychosoc Oncol. 2000;18(2):65-77. 
25. White J. Effects of relaxing music on cardiac autonomic balance and anxiety after acute myocardial infarction. Am J Crit Care. 1999;8(4): 220-230.

26. Burns S, Harbuz M, Huckebridge F, Bunt L. A pilot study into the therapeutic effects of music therapy at a cancer help center. Altern Ther Health Med. 2001;7(1):48-57.

27. Allen K, Golden L, Izzo J. Normalization of hypertensive responses during ambulatory surgical stress by perioperative music. Psychosom Med. 2001;63(3):487-492.

28. Browning C. Using music during childbirth. Birth. 2000;27(4): 272-276.

29. Haun M, Mainous R, Looney S. Effect of music on anxiety of women awaiting breast biopsy. Behav Med. 2001;27(3):127-132.

30. Schneider N, Schedlowsky M, Schumeyer T, Becker H. Stress reduction through music in patients undergoing cerebral angiography. Neuroradiology. 2001;43(6):472-476.

31. Weber S, Neussler V, Willmans W. A pilot study on the influence of receptive music listening on cancer patients receiving chemotherapy. Int J Crit Care.
32. Guzzetta C. Effects of relaxation and music therapy on patients in a coronary care unit with presumptive acute myocardial infarction. Heart Lung. 1989;18(6):609-616.

33. Stuckey H, Nobel J. The connection between art, healing, and public health: a review of current literature. Am J Public Health. 2010;100(2): 254-263.

34. Bolwerk C. Effects of relaxing music on state anxiety in myocardial infarction patients. Crit Care Nurs Q. 1990;13(20):63-72.

35. Davis-Rollans C, Cunnigham S. Physiologic responses of coronary care patients to selected music. Heart Lung. 1987;16(4):370-378.

36. Updike P. Music therapy results for ICU patients. Dimens Crit Care Nurs. 1990;9(1):39-45.

37. Kemper KJ, Danhauer SC. Music as therapy. South Med J. 2005;98: $282-288$.
Journal of Multidisciplinary Healthcare

\section{Publish your work in this journal}

The Journal of Multidisciplinary Healthcare is an international, peerreviewed open-access journal that aims to represent and publish research in healthcare areas delivered by practitioners of different disciplines. This includes studies and reviews conducted by multidisciplinary teams as well as research which evaluates the results or conduct of such teams or

\section{Dovepress}

healthcare processes in general. The journal covers a wide range of areas and welcomes submission from practitioners at all levels, from all over the world. The manuscript management system is completely online and includes a very quick and fair peer-review system. Visit http://www.dovepress.com/testimonials.php to read real quotes from published authors.

Submit your manuscript here: http://www.dovepress.com/journal-of-multidisciplinary-healthcare-journal 